\title{
Re-designing the everyday; The use and perception of time among cancer patients combining work and treatment
}

\author{
Hauge, Bettina
}

Published in:

Time \& Society

Link to article, DOI:

10.1177/0961463X15577255

Publication date:

2016

Document Version

Peer reviewed version

Link back to DTU Orbit

Citation (APA):

Hauge, B. (2016). Re-designing the everyday; The use and perception of time among cancer patients combining work and treatment. Time \& Society, 25(2), 193-212 . https://doi.org/10.1177/0961463X15577255

\section{General rights}

Copyright and moral rights for the publications made accessible in the public portal are retained by the authors and/or other copyright owners and it is a condition of accessing publications that users recognise and abide by the legal requirements associated with these rights.

- Users may download and print one copy of any publication from the public portal for the purpose of private study or research.

- You may not further distribute the material or use it for any profit-making activity or commercial gain

- You may freely distribute the URL identifying the publication in the public portal

If you believe that this document breaches copyright please contact us providing details, and we will remove access to the work immediately and investigate your claim 


\section{Re-designing the everyday; \\ The use and perception of time among cancer patients combining work and treatment}

This article describes how time was used dynamically by a group of people at risk of losing their lives. It is shown how these people appeared to experience a change in the relationship between inner and outer time and that time literally was felt in this situation. An empirical investigation of 16 cancer patients performing their jobs while going through demanding treatment programs found time as their main motive for working while being seriously ill. Actions at work point to a time ahead, so by taking part in the time at the workplace they were inscribed in a future presently under pressure by their cancer diagnosis. The article describes how cancer struck women and men perceived time in their different life-worlds, at work, at home on temporary sick leave, and at the hospital, and it shows how these perceptions changed during the process of recovery.To these people time appeared in three forms: A time beyond control, realizing that they had cancer; taking control of time, discovering that they could go to work; the time of the future, which was their new perception of time as cured. This new perception of time reflected the incidental discovery of the cancer, realizing life as coincidental. Having their life time threatened made them feel vulnerable and liminal (neither sick nor well, but on the way to recovery). This vulnerability can be seen as the result of a breakdown of our taken-for-granted spacetime world. For these people, going to work seemed to reduce the unbearable waiting time towards recovery by re-establishing links to a well-known life-world, the workplace.

(262 words) 


\section{Re-designing the everyday; \\ The use and perception of time among cancer patients combining work and treatment}

\section{Introduction}

'Why I work? But I love it. Should I just sit down, do nothing, and wait for my death?'

Jane, having breast cancer and going through chemotherapy, working as a traffic planner

Jane was one of 16 Danish informants - 14 women and 2 men - with a life threatening cancer disease participating in my research study about motives for combining work with physically and mentally demanding cancer treatment programmes ${ }^{\mathrm{i}}$. So far extensive occupational health research has been done on return-to-work issues, studying for instance how work has been adjusted (or not) to the worker returning to the workplace after a period of sickness absence whether caused by injury, mental disorder, chronic diseases, back pain, or cancer (to name but a few: Aust et al 2012; Dekkers-Sánchez et al 2011; Lund 2003; Tamminga et al 2012). Investigating people who are actually in their disease and how people combine work and treatment, precisely distinguishes this study from return-to-work studies and may shed new light on the contribution of work to the individual.

Comments like Jane's are frequently heard at hospitals. According to interviews and a survey among hospital staff, many patients try to combine treatment with work and thus practice what is known as 'presenteeism' (Aronsson, Gustafsson \& Dallner 2000) ${ }^{\mathrm{ii}}$. Presenteeism basically means 'attending work while you are/feel ill', in this case even life threatened, as opposed to 'absenteeism', staying at home while ill (Johns 2010). Both concepts involve time: Time spent, at home or at work, being sick.

Although the phenomenon of absenteeism and presenteeism must surely have existed at all times they have only recently gained interest among the social sciences. This emerging interest may reflect an increased focus on the high societal costs connected to sickness absence, such as payment of sickness benefits, loss of productivity, and the risk of losing one's job in case of long-term sickness absence. Also the nature of the 'health event' that triggers either absenteeism or presenteeism has been investigated; 'health event' as either acute (like the flu), episodic (like migraine), or chronic (like the onset of diabetes) (Johns 2010: 531-32). But whereas severe stomach flu is likely to provoke absence and the early diagnosis of diabetes is likely to prompt presence, cancer, however, is unpredictable and may be represented by all three categories: Acute, in the sense that the diagnosis leaves the person in acute mental distress and in need of acute treatment; episodic, when the disease is followed by a positive prognosis and treatment is for a limited amount of time (yet even then, cancer struck people fear for their lives which eliminates the 'episodic' character of the event); and chronic, if they have to take medicine or get follow-up investigations, such as control scans, for the rest of their lives (which was the case for several of my informants). Not only the nature of the health event has an impact on presenteeism or absenteeism, context is naturally important too: A sore throat may stimulate absenteeism for a singer, presenteeism for a pianist - and a cancer patient who works in environments with a risk of infection is discouraged from practicing presenteeism. This reflects the interaction between the person (the exact illness) and the specific occupation. It has further been proposed that work context factors and personal factors (attitudes, personality, and gender) influence the choice of absenteeism or presenteeism, and that job insecurity, strict attendance policies, a positive attendance 
culture, teamwork, dependent clients, and adjustment latitude in the job favors the occurrence of presenteeism, while easy replacement favors absence. Obviously countries with no sickness benefits or other reimbursement arrangements are likely to see presenteeism only. This is not the case in Denmark, and although rules and regulations on sickness benefits are many and quite complex, the general rule is that the sick worker is reimbursed for the full monthly salary (when working in white collar jobs or at workplaces governed by collective agreements). Casual staff paid by the hour receives sickness benefit rates. Certain legal arrangements attempt to safeguard cancer patients, realizing that their treatment often lasts a year or more and individual workplaces may also offer workers with life threatening diseases special help, such as paid access to extra hospital investigations. Many of these structural arrangements exist to help the worker in a situation coined by fear, confusion and distress, but also rely on the idea that they may prompt a quicker recovery.

Apart from the contextual or structural explanations behind absenteeism or presenteeism, according to Johns, "it seems reasonable to expect that those with positive work attitudes and favorable justice perceptions would, on the margin, exhibit presenteeism, as would workaholics, the conscientious, and the psychological hardy." (ibid: 532). This may well be the case but, apart from the relation to illness as described above, personal factors behind absenteeism or presenteeism have received very little attention. The focus of this investigation was precisely to contribute to an understanding of personal motives behind presenteeism among people with a life threatening disease and a demanding treatment program to follow. Why do these people choose to spend time at work when their life is threatened? How does work contribute (or not) to the identity of the individual in this particular situation?

When investigating people's motives for trying to work while in treatment for cancer it was clear that the informants had various reasons for working (Hauge 2008, 2012), yet one major reason for combining work and treatment appeared as a reference point throughout the entire process of recovery: Time. This article describes how the cancer struck perceived time at work, at home on temporary sick leave and at hospital, and it shows the change in their time perception from diagnosis to recovery.

Studying how people experience time implies a phenomenological approach. Rather than using institutionalized notions of time this article shows how time is constructed dynamically and how it is experienced by the cancer patients, reflecting that many 'times' may co-exist within the individual, since the experience of time will depend on the context and on potential clashes of different time perceptions. My theoretical points of departure are the time concepts by the sociologist Alfred Schutz (Schutz 1967, 2005): The inner time ('durée’) representing chaos, being unlimited and without structures, and outer time which represents clock time, a quantifiable, structured way of experiencing life and the sociality of life. I shall begin with setting the scene theoretically, by describing main tendencies from the sociology of work regarding the contribution of work to the individual, and empirically, in terms of providing a contextualization of the people investigated and the situation of being diagnosed with cancer.

\section{Views from sociology on the contribution of work to the individual}

While some manage to combine work and treatment with success ${ }^{\mathrm{iii}}$, others do not, but their desire to work reflects that work has a huge importance to the individual and the identity (Graversen \& Larsen 2005, Hochshild 2003a, 2003b, Jenkins 2001). Yet recent sociology of work points to the negative aspects of work due to societal 
changes and a sqeezing of time (Bauman 2000, 2004, 2006, 2007, Beck 1999, 2000, Giddens 1991, Nowotny 1994, Sennett 1999, 2000). One of these voices, sociologist Zygmunt Bauman (2000), claims that many characteristics of the late modern society, the 'liquid modernity', have had a major, negative impact on today's working life and on the individual's experience of work. According to Bauman, when it comes to caring for people and entering into long-term relationships a new mind-set has developed: Where people used to establish long-term relations due to mutual expectations about long-lasting, reciprocal work contracts, these expectations are today entirely changed. The 'long-term' mentality amounted to an expectation born of experience that the respective fates of people buying labor and people selling it were closely and inseparably intertwined for a long time to come. This meant that working out a bearable mode of cohabitation or co-working was 'in everybody's interest', but today this has changed and any foundations of past solidarities are broken:

Once the employment of labour has become short-term and precarious [...] there is little chance for mutual loyalty and commitment to sprout and take root. Unlike in the times of long-term mutual dependency, there is hardly any stimulus to take acute and serious, let alone critical, interest in the wisdom of the common endeavour and related arrangements which are bound to be transient anyway. The place of employment feels like a camping site which one visits for just a few days, and may leave at any moment if the comforts on offer are not delivered or found unsatisfactory when delivered - rather than like a shared domicile where one is inclined to take trouble and patiently work out the acceptable rules of cohabitation. (Bauman 2000: 148-149)

The above quote reflects a view of the modern time as a time of weak ties. In the words of Sennett, fleeting forms of association may be more useful to people than long-term connections (Sennett 1999: 24). The critical voices together (a.o. Bauman 2000, 2004, 2006, 2007; Beck 1999, 2000; Eckersley 2006; Giddens 1991; Nowotny 1994; Sennett 1999, 2000) represent the view of a working life coined by short-term relations and characterized by increased precariousness, uncertainty and demands for flexibility. According to these researchers today's working life is a phenomenon of the present, since fundamental characteristics of our modern society contradicts longterm relations and prohibits the relations such as loyalty and commitment.

The changes in Western societies and in the work life have been suggested to bring about new potential health hazards (partly overlooked in current epidemiology, Eckersley 2006), and emphasized individualism, self-fulfillment, an increased sense of uncertainty, and a rise in personal expectations regarding one's job.Time pressures and structural changes in modern working life do hold negative characteristics and may harm and stress the working individuals (Allvin et al 2006, Eckersley 2006, Lund, Hvid \& Kamp 2010), for instance due to the increasing demand for individual flexibility (Everingham 2002, Hylland Eriksen 2001). Individual flexibility could contribute to increased work satisfaction (Costa, Sartori \& Akerstedt 2006), but is also associated with reduced individual control of work time and performance (MacEachen, Polzer \& Clarke 2008). However, if the working place is regarded as a superficial place to stay and with weak ties, and work itself is experienced as a stressful and hazardous arrangement that implies a loss of control, then what were the reasons for going to work with a life threatening disease like cancer? Out of fear from being laid off? Due to economic needs? For normalizing purposes? Or yet other reasons? These questions were part of the investigation of people's motives for going to work while in treatment for cancer. 


\section{The empirical scene: Contextualizing 'working while in treatment for cancer'}

The findings presented here are based on an empirical study of 16 cancer patients carried out in the period of 2004-2006 ${ }^{\mathrm{iv}}$. Each of the informants worked while going through demanding treatment programs, yet 2 had to stop due to side effects of the treatment. Data were gathered from in-depths interviews and participant observation in the treatment system and at their workplaces. The interviews included 14 women and 2 men. The cancer patients were recruited through hospitals in 3 different regions in Denmark and were at different stages of their cancer (thus in different treatment stages also). They had quite different jobs, from an industrial blue-collar worker at a production line to a senior sales executive with several staff members. The different jobs obviously involved varying degrees of responsibility in the organization they worked in, different wages, as well as varying numbers of colleagues. Also their life situation varied: From a 32-year-old single mother with two little children to a woman in her sixties, close to retirement. This variation was pursued in order to get the benefits of qualitative, ethnographic methods where deep insights, and not generalizations, may be gained. Since the aim was to focus on presenteeism, and individual, personal motives for combining work and treatment, people who had chosen not to work were not a formal part of the study. This might have given an even deeper understanding of the potential contribution of work to the individual. On the other hand, it would also mean that the investigation would become part of the already abundant field of absenteeism and return-to-work studies, rather than proposing new insights into the difficult research area of presenteeism ${ }^{\mathrm{v}}$.

Although the participants in this study went to work they were seriously ill, fighting for their lives and vulnerable, yet at the same time also resilient. This article describes both, since each mode seems to imply a different perception of time as well as a different way of dealing with it: 'Time beyond control' appears in situations where the person experiences her/himself as vulnerable, whereas 'taking control of time' reflects a resilient behaviour. The 'time beyond control' refers to the situation where they received the diagnosis and the following treatment at the hospital, or situations at home when waiting for results of tests. In these cases they were out of control in terms of control over their bodies, their response to the treatment, and the amount of lifetime they expected to have left. 'Taking control of time' refers to situations where the cancer struck people reacted on their vulnerable situation by showing different kinds of resilience, like when they changed their diet, did exercises or went to work.

First I describe patients' experiences of their body when receiving the diagnosis and in the further process of fighting for their lives. Then reasons for practising presenteeism are shown, and a description of the different settings where the informants commute. By comparing the characteristics of each setting, which represents its own life-world, the value of work is explained, and, to these people, the value of work seems particularly related to the linear, future oriented time known to exist at work. I then describe how these women and men once diagnosed by the hospital as 'recovered' from their cancer all recognize the presence of a vulnerable future ${ }^{\mathrm{vi}}$.

\section{Vulnerable bodies: A time beyond control}

Cancer is well-known to cause death and strike at random, across social class, religion, education, job, income and job status. The disease is known to throw the cancer struck people into an existential crisis based on one's life being threatened, and also due to realizations about the unpredictability of life. This was the case for my informants also, who often asked 'why me, why now, was that it, was that really my 
whole life?' Ellen, who was going through chemo therapy and worked as a project manager, exclaims how the cancer influences her state of mind:

"But I don't FEEL sick. I really don't. But I AM, I'm maybe dying from my disease. I get so mad. Oh, it makes me totally furious."

Coping mechanisms and emotional reactions on receiving a cancer diagnosis are individual, as are bodily reactions to treatment programs. Common, however, is that the person receiving a cancer diagnosis is left in a state of shock and with feelings of frustration and anger. The informants referred to feeling less bodily vulnerable over time, yet the feeling accompanied the informants throughout the treatment period. The vulnerability seemed to reflect the uncertain identity of the informants whose bodies were now unstable and suddenly unfamiliar. Throughout the treatment period the informants referred to a feeling of commuting between categories of existential importance: Moving from 'healthy' into an unexpected role as 'life threatened ill', before finally reaching the much aspired status as 'cured'. The treatment period is referred to by many informants as a transitional time, "on-the-way-to-get-better", and a time of becoming familiarized with a new body, adjusting to new appearances after surgery and learning side effects from the treatment. Although all informants had been told to expect to recover in time, they all experienced occasional setbacks. Their belief in getting well was constantly challenged, and the numerous extra tests they all had to take increased their feeling of insecurity. Helle's story illustrates why she feels constantly insecure about the disease and the recovery progress:

"I was 46 years old and found both tumours by myself by a stroke of LUCK. [..] and OH MY, by the end of it I had been through SO many tests and scans.[...] after my first operation I had to get my lungs scanned because the radiologist thought there might be a shadow. Well, I can laugh of it now, I sure couldn't then."

Finding the cancer by luck prompted Helle's insecurity. A common theme among the informants seemed precisely the result of this incidental discovery: a feeling of being vulnerable and liminal (neither sick nor well but in treatment). Schutz refers to a kind of vulnerability as a result of a breakdown of our taken-for-granted space-time world (2005). Schutz talks about living our lives on the level of consciousness of the spacetime world and refers to two types of experiencing this: an inner time (the 'durée') representing chaos, being unlimited and without structures, and outer time which represents clock time, a quantifiable, structured way of experiencing life and the sociality of life. The inner time of the cancer patients is reflected in the words they use to describe their emotional state of mind, going through a period of deep frustration, whereas the outer time represents the actual going to work. All informants refer to waiting time as something that provokes the unpleasant experience of inner time. Ole explained it this way:

"Waiting for the results to tell if the cancer had spread, those were the longest 3 weeks of my life. The insecurity is the worst, the insecurity and the waiting."

Aspects relating to this inner time came forward when my informants described the overwhelming emotions relating to the disease:

"That was the worst, I couldn't even think about the kids, and how they were doing, everyday stuff you know, that you can't keep focus, you keep returning to the disease. [...] I was afraid that I should never be happy again."

Having met the potential death turned the informants into 'strangers' who felt alienated not just from their well-known bodies and emotional state of mind, but from their entire, secure world. Helle described this as 'standing on the outside': 
"It was as if somebody cut the main thread of life. My life was suddenly cut in two. [...] you feel as if you're standing on the outside and that has been really difficult for me; And unpredictable. I was taken totally by surprise. But then again, you don't expect things like this”.

During the entire treatment process many felt distress about losing control over their bodies, as expressed in Rita's statement: "I felt naked in the crowd". Rita's remark reflects a feeling of alienation and of having a body which was 'open' to the public. In a way this was true since very private parts of the body were now being openly and clinically discussed, in different settings, among family members, colleagues at work, and hospital staff. Her body no longer felt safe and private; even fully dressed and wearing her wig she felt estranged from her body, and that the disease was visible to everyone around her. Alienation is a phenomenon described by the psychologist Irvin Yalom (1998) as a common reaction on a crisis; here the crisis was caused by the realization that death cannot be prevented. Of course we all know that we shall eventually die and many may make preparations relating to their demise (wills, funeral wishes, etc.), but to the human mind this is an unbearable recognition in our everyday life. We wisely put this aside and live and enact our lives as if we shall be here forever. The narrative of our life is based on the general idea of a long and happy life and we thus take our life and the world around us for granted. A shock, like the shock of receiving a cancer diagnosis, is described by Schutz as a consequence of a fracture in our way of taking the world for granted. Cancer is an unpleasant eyeopener: The predictability of life is realized as an illusion and life appears not just unpredictable, but coincidental. Having one's lifetime threatened makes people realize the unpredictability and coincidental nature of life, making them physically and mentally aware of time: Time is literally felt, in Ole’s words, "time felt SO long."

Theoretically Schutz argues that it is a general attention to life that makes us feel alive and act in the present, and that paying life attention - which he describes as bodily movements and actions - bridges the two types of time earlier mentioned, inner and outer time (Schutz 1967; Schutz 2005). To Schutz a motive behind an action relates to time: Actions are projected (hence some idea of the future or a time to come is involved), enacted and lived in the present, and continually reflected upon by looking backwards. By orienting the action towards a goal and because it is actively enacted, the action becomes the backdrop for experience and, once reflected upon, of subjective meaning and sense to the individual. Because of this reflection, the action appears teleological: An action is motivated and meaningful, because it is purposive (Schutz 2005:14). Meaning is not only about the lived experience, but also awareness of the experience; hence the two fundamental levels of conscience that involve two different attitudes and two distinct time structures need to be connected. To grasp the experience it is necessary to stop and think, leave the stream of the durée and turn one's attention outwards. The change in attitude implies a change in the temporal structure. From the present, from my present now, I must turn towards the past to make sense of the experience and my action to be performed. Projection of time into space is precisely what is happening in the different life-worlds of the cancer stricken individuals as will be described later, and an action, such as working while ill, is - to the body and mind - a way of being-in-the-world and a way of paying attention to a life now threatened. The following section will illustrate this.

\section{From vulnerable to resilient: Taking control of time}

The importance of working while ill is shown in the following comment. Ole, a 28year-old man awaiting further surgery, explains how cancer destroys the common structure of his family's everyday life and introduces a fundamental fear of losing 
one's life, leaving your dear ones behind. In the context of an insufferable situation Ole introduces work as a mediator:

"During all the time with the chemo we knew what was coming: 'Now it's my fourth time, I have so and so many nights to next time' and then we're able to exist for a couple of more days [...] And this operation, my second, seems to draw out, it can be in a month, they said, and if I have to wait a month I discussed with my work if I could come, may be on reduced time."

The period of not knowing one's progress and being stuck in the structures of the hospital is almost unbearable. To Ole, work seems a way of reducing the vulnerability of the whole situation by reintroducing a linear clock time whose structure and predictability is well-known to the family: working hours. Work represents stability, as opposed to the whole treatment period that can be seen as a transformation ritual (Little et al. 1998; Little 2004), as described by the informants when they talked about becoming 'a different person', getting familiarized with the cancer in their body and the side effects of the treatment as well as the hospital setting. A transformation ritual often also includes new and different space-time experiences, such as those experienced by the cancer patients when they commute between the three settings that now take up all their time: the hospital, the home, and the workplace. Each of these settings is characterized by different time systems, structures and values, such as different aesthetic values. Mette, who works as a senior clerk in a public administrative office, explains why she wears the wig at work, although it is warm and annoying.

"It's not true that having lost your hair doesn't mean a thing, well of course it doesn't mean anything compared to having cancer, but still, it means a lot for appearances and your wellbeing that you have the hair you've always had, instead of looking like, well, like a sick hen."

When Mette refuses to look like a 'sick hen' it is because of the common front stage obligations at work: We try to look our best. Looking like a sick hen may be acceptable back stage among your close relatives, but not at work (Goffman 1958). The bodily adjustment to the norms at a working place is not always easy: Gurli claims to look "like a monster. I can't stand to watch myself in the mirror". The new, hurt body implies new, daily considerations relating to their physical and mental wellbeing, such as: How do I feel today, can I actually go to work? Is my wound leaking too much? Will I need a nap during the day? Will my colleagues help me in case I need it? How will they react if I don't wear my wig?

Managing the impressions of our environment is not all about control: It is also a way of showing the surroundings respect by adapting to cultural norms. All informants, even the nurses who wore uniforms and the factory worker wearing company clothes, stressed that at work appearances matter. In a situation where side-effects from the treatment made them feel and look bad, it was seen as a relief that they had to look normal, even if it meant an effort: "It's those daily activities you need to get back to". Work becomes a way of normalizing a situation out of the ordinary. 'Getting back' to a daily activity like work reflects resilience since work as an everyday life activity requires, in Rune's words, "that you get out of bed and out of the pyjamas, you know, so you have to pull yourself together". When Helle emphasizes her need to convert the cancer into a more common everyday life activity it is because her work tasks represent normality and something very familiar, as opposed to the cancer and the hospital. This was common to all informants. In this sense the seriousness of the illness played a role in their decision to work, providing them with a sense of being 'normal' through normal activities such as doing the job, looking as usual, and taking part of the time and structure at work. 


\section{Commuting between different realities and different times}

The cancer-stricken informants participated in several 'worlds', each being characterized by different time systems, structures and values. Their vulnerability seemed to be construed in the meeting of different worlds, which made this intersection of 'worlds' fundamental for understanding motives for working and how time itself came to be a motive. The significance of work was also construed precisely in the meeting of different worlds with different emotional values and different interests at stake. What it meant to be life threatened ill in different settings - to one's family members, to the hospital staff and to the workplace and one's colleagues - all together shaped the meaning of work. The value of a working life for the seriously ill appeared in the light of these three realities and in the light of the disease that cut across all three worlds, disrupting the structure of the everyday life of the individuals and their families, and, while in treatment, turning the informants into liminal beings with uncertain identities: In a limbo, neither well, nor dying, but 'on-my-way-to-getwell'.

Time felt when people are in transition, moving from a highly undesired, chaotic identity towards a much sought after and desired identity as cured/well, is, of course, not pleasant, but chaos and inner time are set aside (on stand-by) when they go to work, as will be described in the following:

In the treatment system, viz. the hospital, and for the duration of the treatment, time is characterized by anxiety and uncertainty. The diagnosis provides the cancer-stricken individuals with a sense of alienation because they lose faith in the predictability of everyday life. The treatment system makes the self and the identity of the cancerstricken individuals more fragile, in part because in the treatment system they are not recognized for their potential: "You're only a medical record, you feel like a number". In this system, the individual is just one out of many and they are unable to act on the cancer. The individuals with cancer are met by a system in the hospital and an equal relationship based on recognition is not part of this system. What follows from this is that the individuals with cancer feel no belonging to the treatment system, as this feeling depends on feeling equal and the presence of a "living present". The result is a state of a temporary identity of the cancer patients during the treatment process. In a ritual theoretic perspective, the cancer is a transitory ritual. The cancer patients are liminal and the period with cancer is a development process towards recovery, yet the period with cancer is at the same time characterized by a special attention to life; a new physical alertness and a new physical attention are established.

At work the individuals with cancer are met with professional and most frequently personal recognition and sympathy that contributes to the feeling of being important to one's colleagues. Here they are actively part of constructing the living present and can act. The identity contribution from work is therefore in sharp contrast to their experiences in the treatment system. At work, the cancer-stricken individual becomes part of the special time at the workplace that comprises the past, the present and also the future. The individuals with cancer are connected to their colleagues through occupation and based on a premise that they are replaceable. This implies that there is some distance in a workplace. With presenteeism, the individuals with cancer choose an identity as "normal" and the right to define themselves as between-sick-and-cured.

At home, the identity of the individual with cancer was deeply rooted in their role as either mother/father/spouse and linked to basic conditions in the family: love and presence. In this forum, the family member with cancer is irreplaceable. However, a family makes its own demands, so the cancer-struck individuals must in their own 
words "suppress" their own needs. They consider the daytime at home as ineffective, a "waste of time", feeling they have little to do. The time at home is also emotionally difficult because of the fear within the family of losing a loved one. This makes the cancer-struck individual very worried about exposing the people they love to pain and concern. The high degree of emotional intensity in this setting implies that the family is "too close, too frightened" for the cancer-struck individual to talk openly about their disease, their own fears and concerns. This talk, on the other hand, is easier at work, where the individual has a more distanced relationship to the colleagues, and may be dispensable since most job positions can be filled in by others.

To summarize, the three life-worlds represent different values and characteristics as indicated in table 1:

\begin{tabular}{|l|l|}
\hline Life-world & Characteristics of life-world \\
\hline Home and family life & $\begin{array}{l}\text { Personal recognition and identity contribution, but time is chaotic, } \\
\text { coined by fear and insecurity, an emotionally demanding period due to } \\
\text { an irreplaceable position in the family: } \\
\text { "The family is too scared, too close." }\end{array}$ \\
\hline Work and working life & $\begin{array}{l}\text { (Usually) Personal recognition of one's situation and identity } \\
\text { contribution. Time is structured, focused; an emotionally } \\
\text { undemanding place due to emotional distance and one's replaceable } \\
\text { position at the workplace: } \\
\text { "It's nice to share with someone you know, and yet don't really know." }\end{array}$ \\
\hline $\begin{array}{l}\text { Hospital and life in the } \\
\text { treatment system }\end{array}$ & $\begin{array}{l}\text { (Usually) Kind and medically supportive staff, but no individual } \\
\text { recognition; a period and a time coined by waiting and insecurity, } \\
\text { emotionally demanding, and a place with no identity contribution: } \\
\text { "You are just another medical record." }\end{array}$ \\
\hline
\end{tabular}

Table 1: Characteristics of each life-world

The individual characteristics of the three settings and their different emotional demands seemed to encourage going to work while ill. Once at work, these people are at the mercy of the conditions of the working place. In this sense they are also placing themselves in vulnerable positions. However, since they feel even more vulnerable at home, waiting for results, for getting better, and for time to pass, work seems a better place to be.

\section{Finally recovered: A new future, a new time, and a new view on work} "Seize the moment, you know. Oh, I just want to BE in the moment, enjoy life more." Ellen

Seizing the moment is for Ellen a new more sensuous way to be alive. Her comment reflects that life and time is being valued in a new way, one that implies a new use of time: Enjoying the present in its moment. Ellen's comment is representative of all the informants and when interviewed again, this time at the end of their treatment, their take on work appeared slightly changed: Work played a part in the construction of a new narrative, but not the way it used to. As Yalom explains (1998), we live our lives according to the idea of a long lasting life, but to these people this idea had been cut by the cancer. In the process of reframing a new narrative and redesigning their life, new values were included. These values applied to life in general and to working life in particular. Rune 'used to live to work', but has now made major changes in his work attitude:

"I have made a lot of changes in my life. When I come home I turn off the phone. I never did that before. [...] I look differently on how the day should be: That I need to spend more time on 
my wife and my children and not as much on myself that I used to. I think I used to be more selfish, first work then the family, PERHAPS, if I didn't have sports I wanted to go to. I've completely stopped that. I couldn't care less about that now."

Having realized that life is short and coincidental, 'so you'd better make the best of it' as Rune and others state, appeared to be a driving force for changing and re-designing their everyday life. This realization appeared to have made Rita more assertive and aware of her own needs:

"I've become better at putting my foot down. Give a quick response. I was far too nice before, you know, I'm probably from that generation. But that's all over now, 'cause there is no reason to expose anything, it's all about living in the moment, live your life when you have the chance. That's how I work, but I prioritize myself higher and think: 'Do I really want to do that job?"

The above quotes together indicate that new values appeared during the process of recovery. Choosing to combine work and treatment was seen as a way of creating a new narrative, one that among other things referred to helping co-workers at the workplace and to be part of the process at work where common, future oriented goals or tasks were required. The workplace has a time of its own; work implies a specific time, one that relates to the future. An aspect of working is that the individuals with cancer share time and space with their colleagues. It is due to the temporality of work and the inherent sociality of the workplace that the practices of working life provide the informants with orientation and significance; and, by sharing time, they also age together and thus take part in each other's advancing life. That the actions at work indirectly connect the cancer-stricken individuals to the future relate to the fact that the tasks at the workplace are pointing forward, to some target to be met in the future. Thus, through work, the individuals with cancer are inscribed in the future; a future made uncertain by the cancer, marginalizing it as 'possible' and not to be taken for granted.

\section{Concluding remarks and some theoretical implications}

The article has described how this group of cancer-stricken people despite stressful jobs and side effects from the treatment try to work while in a treatment program. Two mechanisms seem to account for their presenteeism:

1. The significance of a working life as a result of a clash between the different 'times' and the specific characteristics of the treatment system, the private life and the workplace.

2. The potential of work in connecting the cancer-stricken individual with a wellknown world and in serving as an element in the re-design of their everyday and their new life narrative, now with the recognition of a future that needs to include the hardship of knowing that life will eventually end.

I have proposed that much of the value of work lies in its ability to connect the cancer-stricken individual with the surrounding healthy world and the future in which they are inscribed through work. When the cancer-stricken individuals are working they are inscribed in the sociality, history and the specific time, the future, of the workplace. These findings seem somewhat contradictory to the theories describing the late modern society as 'liquid modernity' where work is a phenomenon of the present. According to Bauman, work itself is a short-term alliance and may thus figure as all but making workers inscribed in the future; yet it is precisely through their work that the individuals with cancer are inscribed in the future. This challenges the current sociology of work focusing on the negative aspects of a working life. The changing conditions identified in the modern working life do occur and may even damage the individual, and some of 
the informants also referred to a stressful job or even an unpleasant work environment. But the fact that these cancer-stricken people associate work with the future and despite stressful jobs choose to go to work contradicts that current work-life is characterized by increased precariousness, uncertainty and flexibility and a place where we spend time without bonding with our coworkers. Or rather: The empirical findings show that despite a work-life often coined by precariousness, uncertainty and demands for flexibility people went to work while going through a cancer treatment program because of the time perception involved at the workplace, one that involved a future, and most referred to friendly and helpful co-workers.

Motivations for presenteeism were also linked to their thoughts about a working life and the specific tasks after the cancer. Working in this situation provided them with a concrete connection to the world, an anchoring of their vulnerable bodies in the world, precisely because work is performed through bodily and sensory practices internalized in their bodies. The potential of work comes from its constituting a specific physical possibility to the cancer-stricken individuals of feeling connected with the world and the future, and in the ability of the workplace in rebuilding the everyday life. By taking part in the work-life the individual is part of the history of the workplace and in the lives of the co-workers. Work thus enabled the individuals with cancer to connect physically, socially and historically to the world and to a future which in their personal life was currently threatened. By inscribing in working life the individuals with cancer became part of a continued narrative. Presenteeism thus involved a contribution to their identity due to the specific characteristics of the workplace. An understanding of their motives was therefore achieved by examining their special relationship with time and in the fact that the significance of work was shaped by the different contexts between which the individual commuted. Through working, work itself was transformed from an external relationship or a pure objective/means relationship into a relationship representing 'life' through a dialogic development process between the sick individuals, the colleagues and the concrete work assignment.

The significance of work is construed in the meeting between discursive fields characterized by different emotional intensities, interests and times. Consequently, a cancer patient practicing presenteeism commutes between spaces AND times and in relations that will have an impact on his or her choosing or rejecting work while having a life-threatening disease. Practicing presenteeism is one way of trying to take back control of one's lifetime and may therefore also be seen as practicing the right to define one's own identity and enacting oneself, in Schutz' words, wide awake, and with a view to a future. Research on cancer stricken people's experiences of time may help us improve our ways of dealing with patients or cancer stricken colleagues, making us better at catering to their needs in this highly vulnerable situation. Thus research on presenteeism in general may help us to understand what is at stake when people try to combine work and treatment, and with this knowledge practices or programs may be developed, supporting those who wish to try it.

This research received no specific grant from any funding agency in the public, commercial, or not-for-profit sector 


\section{References}

Allvin M. P., G. Aronsson, T. Hagström, G. Johansson \& U. Lundberg (2006). Gränslöst arbete: Socialpsykologiska perspektiv på det nya arbetslivet. Malmö: Liber AB.

Antonovsky, A. 1979. Health, Stress and Coping. San Francisco, Jossey-Bass. 1979

Aronsson, G., Gustafsson, K., \& Dallner, M. 2000. Sick but yet at work. An empirical study of sickness presenteeism. In: Journal of Epidemiology and Community Health, 54(7): 502509.

Aust, B, Helverskov T, Nielsen MBD, Bjorner JB, Rugulies R, Nielsen K, Sørensen OH, Grundtvig G, Andersen MF, Hansen JV, Buchardt HL, Nielsen L, Lund TL, Andersen I, Andersen MH, Clausen AS, Heinesen E, Mortensen OS, Ektor-Andersen J, Ørbæk P, Winzor G, Bültmann U, Poulsen OM. 2012. The Danish national return-to-work program - aims, content, and design of the process and effect evaluation. In Scandinavian Journal of Work, Environment \& Health 2012; 38(2): 120-133

Bauman, Z. 2000. Liquid modernity. Polity Press

Bauman, Z. 2004. Identity. Polity Press

Bauman, Z. 2006. Liquid fear. Polity Press

Beck, U. 1992. Risk Society: Towards a New Modernity. Sage: London

Beck, U. 2000. The brave new world of work. Polity Press

Borritz, M. 2006, Burnout in human service work, Arbejdsmiljøinstituttet.

Cancer Registeret. 2009: Nye Tal fra Sundhedsstyrelsen. Årgang 13, Nr. 5, December 2009, http://www.sst.dk/publ/Publ2009/DOKU/cancerreg/cancerregisteret_2008.pdf

Costa G., Sartori S., Akerstedt T. 2006. Influence of flexibility and variability of working hours on health and well-being. In: Chronobiology International. 2006; 23(6):1125-1137.

Dekkers-Sánchez PM, Wind H, Sluiter JK, Frings-Dresen MHW. 2011. What promotes sustained return to work of employees on long-term sick leave? Perspectives of vocational rehabilitation professionals. In Scandinavian Journal of Work, Environment \& Health 2011; 37 (6): 481-493

Donzelot, J. 1991. Pleasure in work. In: The Foucault Effect. Studies in Governmentality. Buchel, Gordon \& Miller, eds. University of Chicago Press, pp. 251-80.

Eckersley R. 2006. Is modern Western culture a health hazard? International Journal of Epidemiology. 2006; 35(2): 252-258.

Eshøj, P. 1996, Sygefravcer - hvorfor? (Sickness absence - why?) Sydjysk Universitetsforlag: Esbjerg.

Feuerstein, M. (ed). 2009. Work and Cancer Survivors. Maryland: Springer.

Giddens, A. 1991. Modernity and self-identity. Polity Press

Goffman, E. 1959. The Presentation of Self in Everyday Life. Doubleday Anchor Books: New York.

Graversen, G. \& Larsen, H. 2004. Arbejdslivets psykologi. Hans Reitzels Forlag: København

Hauge, B. 2008. Krceftramte - på arbejde. Betydninger af et arbejdsliv for livstruende syge, 1st edn, University of Copenhagen, Department of Sociology, Copenhagen.

Hauge, B. 2012. When the Meaning of Work Frames the Meaning of Life; The Significance of Work to Danish Cancer Patients working while in a Treatment Programme. Book chapter in Current Issues in Sociology: Work and Minorities. Athens: Athens Institute for Education and Research,

Hochschild, A. R. 2003a. The commercialization of intimate life. University of California Press: Los Angeles.

Hochschild, A.R. 2003b. The timebind. When work becomes home - and home becomes work. Metropolitan 
Holstein, J. A. \& Gubrium, J.F. 2000. Analyzing interpretive practice. In Handbook of Qualitative Research, Denzin \& Lincolk (eds.). Sage: London. Pp. 487-508

Jacobsen, M. H \& Tonboe, J. 2004. Arbejdssamfundet. (Work Society). Hans Reitzels Forlag.

Jenkins, R. 1996. Social Identity. Routledge

Johns, G. 2010. Presenteeism in the workplace. A review and research agenda. In: Journal of Organizational Behavior, 2010; 31: 519-542

Klein, L. 1963. The meaning of work. Pamphlet. Fabian society.

Kleinman, A. 1989. The Illness Narratives: Suffering, Healing, and the Human Condition. Basic Books.

Kvale, S. 1996. InterView. Sage, London

Little, M. 2004. Chronic Illness and the Experience of surviving Cancer. In: Internal Medicine Journal, 2004, vol. 34, pp. 201-202

Loisel, P. L., P., Côté, P., Durand, M.-J., Franche, R. L., Sullivan, M. J. L. and all other mentors of the program. 2005. Training the Next Generation of Researchers in Work Disability Prevention: The Canadian Work Disability Prevention CIHR Strategic Training Program. Journal of Occupational Rehabilitation, 15(3), 273-284.

Lund, H., Hvid, H. \& A. Kamp. 2010. Perceived Time, Temporal Order and Control in Boundaryless Work. In: Advances in Occupational, Social and Organizational Ergonomics. Peter Vink \& Jussi Kantola (eds.). 2010. CRC Press LLC. Pp. 250-261.

Lund, T. 2003. Tilbagevenden Til Arbejde (Return to Work). Arbejdsmiljøinstituttet, København

MacEachen E., Polzer J., Clarke J. 2008. You are free to set your own hours: governing worker productivity and health through flexibility and resilience. In: Social Science \& Medicine, 2008; 66(5): 1019-1033

Nowotny, H. 1994. Time. The modern and postmodern experience. Cambridge: Polity Press.

Schutz, A. 1967. The phenomenology of the social world. London: Heinemann Educational Books Ltd.

Schutz, A. 1976. Fragments on the Phenomenology of Music. In: F. J. Smith (ed.) In Search of Musical Method, pp. 23-71. London: Gordon and Breach Science Publishers.

Schutz, A. 2005. Hverdagslivets sociologi. København: Hans Reitzels Forlag

Schutz, A. \& Luckmann, T. 1989. The structures of the life-world. Northwestern University Press: Evanston

Sennett, R. 1999. Det fleksible menneske. Forlaget Hovedland (The Corrosion of Character, The Personal Consequences Of Work In the New Capitalism, Norton. 1998).

Sennett, R. 2000: Street and Office: Two Sources of Identity. In: Hutton, R. \& Giddens, A. (eds.): On the Edge: Living with Global Capitalism. London: Jonathan Cape, pp. 175-190.

Tamminga SJ., de Boer AGEM., Verbeek JHAM., Frings-Dresen MHW. 2012. Breast cancer survivors' views of factors that influence the return-to-work process - a qualitative study. In: Scandinavian Journal of Work, Environment \& Health 2012;38(2):144-154. 


\begin{abstract}
${ }^{\mathrm{i}}$ All cancer-stricken individuals naturally need some periods of absence from work due to surgery, hospital visits, side effects from treatment, etc. The informants had absence periods that differed in length but all tried to combine work and treatment, going to work as much as possible. Of course every cancer patient is not physically or mentally able to manage to combine work and treatment, nor is it possible or recommendable for all types of jobs. Breast cancer and testicular cancer are, however, two types of cancer where the combination of work and treatment may be physically possible.
\end{abstract}

${ }^{\text {ii }}$ Each year appr. 30,000 new cancer incidents are recorded in Denmark and of these some 4,500 breast cancer. Breast cancer represents $23.1 \%$ of the total amount of cancer diseases among women, whereas testicular cancer represents $1.8 \%$ of the total male cancer incidents per year, corresponding to appr. 280 men each year (Cancer Register 2009: 8). The informants in this study were diagnosed with breast cancer or testicular cancer, and all of them had to go through more than one surgery and long treatment programs with chemotherapy and radiation.

iii It should be mentioned that two women with breast cancer were interviewed for their counter stories, providing me with information on why they chose not to work (absenteeism). However, the intention of the study was not a comparative study or to identify structural reasons behind working or not.

iv The study formed the basis for my PhD (Hauge 2008) and parts of the methods and analysis sections are published in a book chapter (Hauge 2012). All data for the research were gathered during the period of 2004-2006. The design was explorative to allow for dynamic and open questions. Mixed methods were chosen to avoid situations that might only appear in a specific geographical area (such as special test cancer treatment programs that would make a working life impossible). By using different qualitative methods perspectives were gained on the significance of work from different angles: Treatment staff (3 nurses, 3 doctors), co-workers/employers (4 interviews), and the cancer struck individuals themselves (18); as secondary informants: Two people who had chosen not to work (counter stories). The methods used were: 1 focus group of 4 cancer patients, some working, some not; participant observation at 11 workplaces and at 2 oncological wards; a quantitative survey among nurses at oncological wards a.o. asking about motives regarding work that they have heard from patients; in-depth, semi structured interviews. A total of 18 main informants (cancer struck people combining work and treatment) participated, yet in the end data from 2 were not included. This was due to a poor quality of one transcript and because the condition of one informant worsened. Informants were recruited through the hospitals who knew which would be physically well enough for me to approach. The different qualitative methods gave rich data and were used also for triangulation. The approach was inductive; theories were used ex ante to allow as open an analytical process as possible (Kvale 1996).

$\mathrm{v}$ 'Difficult' in several ways: It is often very hard to find people that practice presenteeism, since they do not appear in statistics and may not be registered as 'sick and still at work' at the workplace which then makes contacting people a practical problem, and besides it may be (and is) an ethical problem to contact them in the first place, since they may not want to reveal their disease/sickness to others.

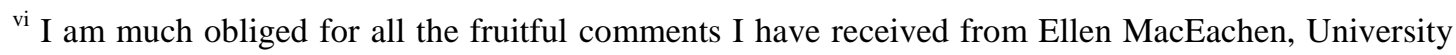
of Toronto, my mentor at the Work Disability Prevention Program, Sherbrooke University. 